This is an Open Access article, distributed under the terms of the Creative Commons Attribution licence (http://creativecommons.org/licenses/by/4.0/), which permits unrestricted re-use, distribution, and reproduction in any medium, provided the original work is properly cited.

\title{
Transitional Burials in Late Antique Villas in the North-Western Provinces: Assessing Distributions and Characteristics
}

\author{
JAMES DodD \\ Faculty of Humanities, Free University Amsterdam, The Netherlands
}

The end of the villa landscape in the north-western Roman provinces is characterized by significant transformation. One facet is the use of the villa complex and its surrounding area for funerary purposes. Traditionally, these burials have been divided into large-scale reuse of sites in the Migration period and small-scale transitional burials. The study of the latter has previously often been misguided or neglected. In this article, the author examines these transitional burials, addresses their historical background, and presents a new approach for assessing the scale, temporal distribution, and characteristics of a group of sites with funerary evidence in Belgica, Britannia, and the Germanic provinces.

Keywords: Late Antiquity, north-western provinces, burial traditions, villa transformation, rural settlement, Migration period

\section{INTRODUCTION}

Rural communities in the north-western provinces of the Roman Empire experienced widespread transformation during Late Antiquity. This shift is clear in the development of new productive practices and habitational styles in Roman villas between the third and fifth centuries $\mathrm{AD}$, a topic repeatedly addressed in the literature of the last few decades (e.g. Van Ossel, 1992; Chavarría, 2004; Dodd, 2014, 2019). Despite this, overviews have lacked a datadriven approach to specific elements of this transition, especially in the funerary sphere and more specifically among the so-called 'transitional burials' at villa complexes. The burials under investigation here have generally been labelled as 'transitional' in that they are between the superficially 'neat' rural cemeteries of the Middle Roman period (Ferdière, 1993; Hatton, 1999: 160180; Kießling, 2008) and the later cemeteries arranged in rows of graves (the so-called Reihengräberzivilisation; Halsall, 1995: 913). Transitional burials have been considered 'secondary' in that they use features that were not originally designed for mortuary purposes. These burials differ from more 'formal' Late Antique cemeteries, both urban (e.g. Tongres in Belgium [Lesenne, 1975: 81-86] and Poundbury in south-west Britain [Farwell \& Molleson, 1993]) and rural (e.g. Bradley Hill in 


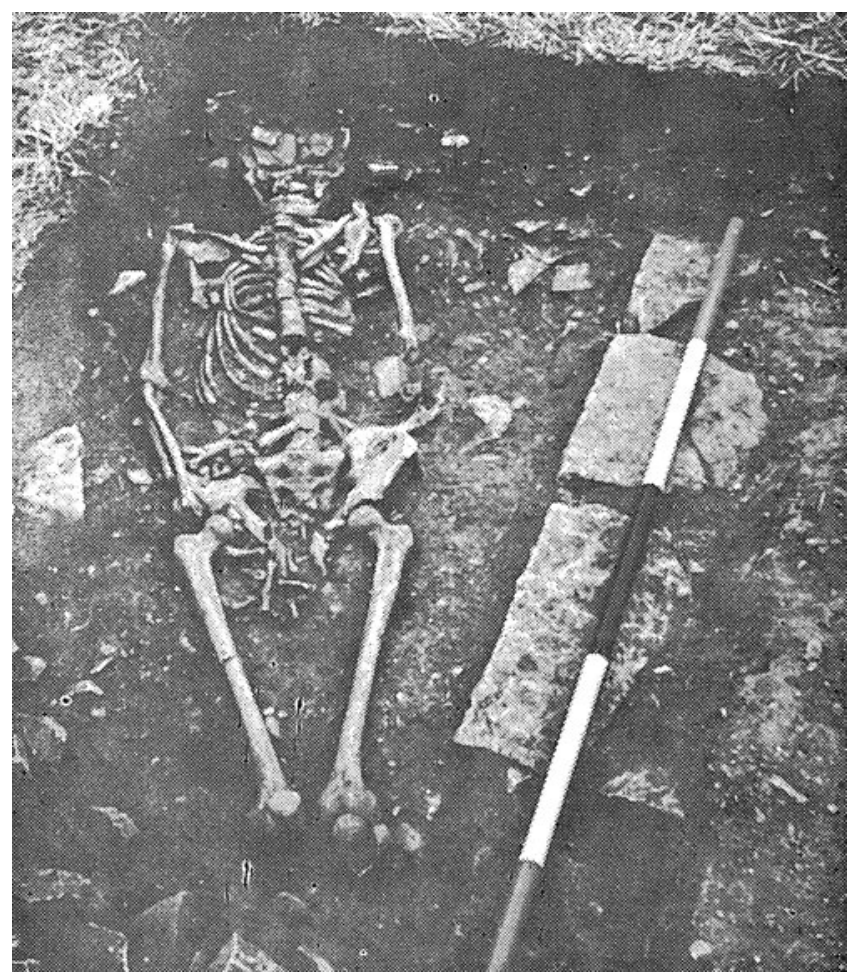

Figure 1. A 'transitional burial' in a villa context: inhumation in the east building at Ilchester Mead (from Hayward, 1982: fig. 21). By permission of Toucan Press.

south-west Britain: Leech, 1981), in that they are characterized by a haphazard approach to inhumation (Figure 1).

\section{EARLY INVESTIGATIONS}

A long tradition of explanation is attached to transitional burials at Roman villas and the wider transformation or abandonment of such rural establishments. These aspects were used to support the 'Gibbonist' tradition (Lewit, 2001), which painted a picture of a declining empire (for general approaches, see Rémondon, 1964, 71; Pignoil, 1972; Gorges, 1979: 43-45). The narrative of 'Decline and Fall' was rooted in the literary sources, with archaeology playing a supporting role in painting a pessimistic account of Late Antiquity. For the villa landscape, its archaeology was used to highlight the destructive nature of Barbarian invasions (Grenier, 1934: 890900; Wightman, 1985: 219-22) and to stress the end of the socio-economic norms of the Classical world.

The wider transformation of villa sites, including transitional burials, was addressed with a biased language: phrases such as 'type d' habitat précaire' (a phrase for poorly constructed occupation; Lewit, 2005: 254; see also Mattingly, 2007: 534) were used to describe archaeological features that appeared to reuse or damage earlier 'Romanized' elements. In English, the term 'squatter occupation' typically covers all of these. Squatter occupation was dismissed as an insignificant phase before the eventual abandonment of sites, or simply attributed to the 'Germanic' 
reuse of sites. This has led to serious deficits in our understanding of transformation at villa sites in Late Antiquity and the early medieval period (Storrie, 1908; Whiting, 1941).

Nowhere is this more apparent than in the reuse of villas for funerary activities. The early investigation of transitional burials was highly fragmented by nationallinguistic boundaries, although the analysis of the graves developed within the same broad framework. Specific explanations were repeatedly employed to describe and explain away the presence of Late Antique burials at villa sites (Figure 2), with implausible narratives deployed in individual cases (Oswald, 1937: 158-60):

'How did the skeleton on the wall come there? The adjoining rooms and all the levels of this period bore traces of a fierce fire. It is perhaps permissible to suggest that these people were trying to escape from the burning building and that as the man on the wall passed over the threshold of the door the lintel collapsed on top of bim, crushing the body into the distorted condition in which it was found. It is also possible that the other two people met their death in a collapse of the outer wall; certainly the skeleton of 2 was covered by wall stones, and at this point the foundation of the wall had subsided sideways in a northerly direction.'

The use of 'specific explanations' has resulted in case-by-case study of transitional burials with individuals considered as everything from the victims of murder (Boon, 1950: 18, 1993: 78-80) to looters who improbably crawled into the ruins of a Roman town at Kingscote in western Britain to expire (Swain, 1976: 21). At Brislington (Bristol), the interpretative options for three burials in a well is piracy, war, or suffocation in the fire which destroyed the site in the second half of the fourth century (Barker, 1901: 289-90). In northern Gaul, the development of a 'specific explanation' was influenced by the identification of an occupation hiatus in the late third century AD.

Nineteenth-century investigation established a phase of abandonment and presumed destruction of a vast number of sites in Germania Inferior and Belgica (Grenier, 1934: 890-900), and destruction horizons and abandonment phases were linked to the breakdown of Roman control during the third-century crisis (De Maeyer, 1937: 290-95). Following the foundation of the German ReichsLimeskommission and its subsequent excavations along the limes (Roman-Germanic frontier) between 1894 and 1900, this was explicitly linked to a fall of the limes, which stated that the Romans abandoned the Rhine in AD 259/260 (see Heeren, 2016: 185-88). It was assumed that the collapse of the limes allowed subsequent Barbarian incursions across the Rhine which destroyed or forced the abandonment of most of the villas in Germania Secunda and Belgica. Limited Late Antique occupation at sites in Germania Secunda was explained as involving Barbarian groups unable to comprehend the correct use of Romanized architectural elements (Joerres, 1886: 92-93). Transitional burials were an important part of this interpretation, especially those without defined features. Such burials were linked to Germanic raiding and it was widely assumed that haphazard burials in villas were the victims of the raiders (Schuermans, 1867: 246).

\section{Recent Approaches}

From the 1970s onwards, it has become increasingly rare to evaluate transitional burials in the terms described above. Narratives of 'squatter' occupation were reexamined, and more nuanced narratives of 


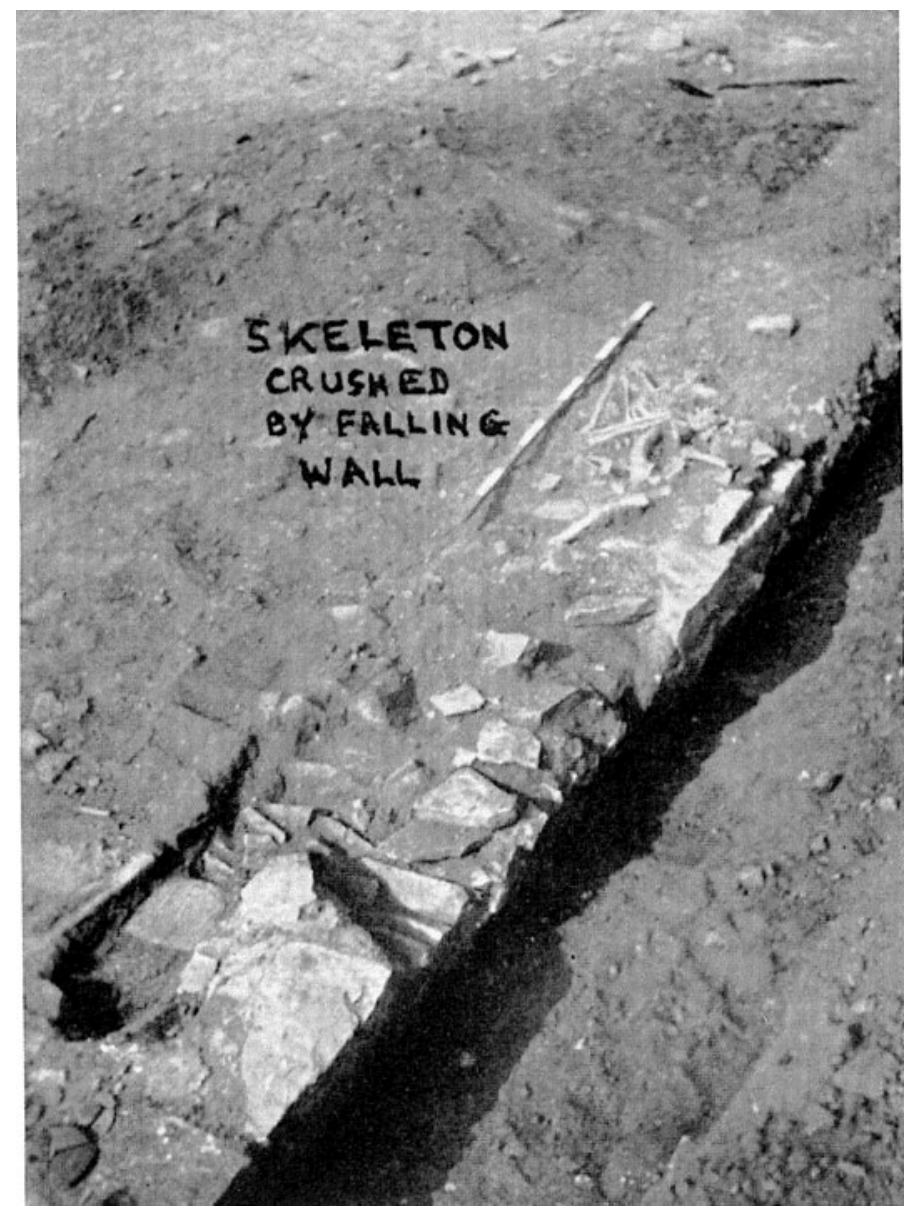

Figure 2. Example of a 'specific explanation' of a Late Antique transitional burial at the Norton Disney villa (from Oswald, 1937: 157, pl. XLIII). By permission of Cambridge University Press and the Society of Antiquaries of London.

'villa transformation' were developed (Petts, 1997: 102-03; Christie, 2004: 827). These new narratives focused on the economic basis of rural transformation (Lewit, 1991; Van Ossel \& Ouzoulias, 2000) and emphasized the transformative nature of Late Antiquity society (Petts, 1997; Lewit, 2003, 2005; Chavarría, 2004, 2007). This development went hand-inhand with the changing nature of the academic consensus, which increasingly stressed that the rejection of Classical traditions cannot be equated with socio-economic decline without resorting to overly simplistic models (e.g. Esmonde-Cleary, 1989; Van Ossel, 1992; Gerrard 2013).

Within mortuary archaeology, new evidence has prompted a shift in our perception of cemeteries in Late Antiquity. Large Late Antique cemeteries have undergone further analysis (e.g. in northern Gaul: Brulet, 1990) whilst scholarship has begun to focus on the ritual and meaning of burials (Ripoll \& Acre, 2000: 88-94; Chavarría, 2018) and move towards a more rigorous analysis of burials in the Late Roman period (Gerrard, 2015). Although the theoretical 
framework has changed, and the academic consensus has moved away from a simplistic model of 'Decline and Fall', there has been little analysis of transitional burials at villa sites and an almost tacit acceptance of these explanations for transitional burials in villa sites. The critical investigation that exists (e.g. Morris, 1992; Scott, 1999, 2018) has been dwarfed by the lack of large-scale analysis. Instead, modern scholarship has moved to placing these burials within the broader framework provided by the Christianization of the landscape (Percival, 1992; Cantino Wataghin, 1999; Ripoll \& Acre, 2000: 74-86; Lewit, 2003: 262-63), viewing decaying or abandoned villas as focal points within the wider countryside. The evidence behind these assumptions is either non-existent or has been 'cherry-picked' from across a variety of Roman provinces with increasingly divergent settlement trajectories.

\section{The Dataset}

The dataset in this study consists of a regionally representative sample of fortythree villa sites with evidence of transitional burials (Figures 1 and 2; Table 1). Four distinct regions of the north-western provinces were chosen to provide diverse microregional studies in socio-economically different regions, capable of interacting with each other on a statistical level. These sites are unequally spread across Britannia, Belgica, and the Germanic provinces (Table 2).

The transitional burials were defined along relatively loose parameters. The burials are identified as graves superimposed on features that were not originally designed for funerary purposes. This includes main buildings, agricultural buildings, and courtyard spaces or compounds around villa complexes. These inhumation burials, sometimes termed 'secondary burials', are morphologically varied; but we can often observe a link between the position of a grave and walls, pavements, or courtyard alignments of the villa complex (Figure 3). This definition does not include larger sites which could be interpreted as longer-term cemeteries, for example at Llantwit Major in Wales (Storrie, 1908) or those which have been identified as 'Germanic', for example, Rosmeer-Dieperstraat in Belgium (De Boe \& Van Impe, 1979).

Spatially, this study has limited the collection of data to the villaterrein. This Dutch word has no precise English equivalent but is a useful moniker. Generally, it refers to the area of a villa complex, including courtyards and open spaces as well as residential and productive zones and this study will use the term in this form. As for abandonment and transformation, these are two important linked terms used here. Traditionally viewed as a linear process (Schiffer, 1987: 89), abandonment consists of a series of interlinked activities that defy simple categorization (Cameron \& Tomka, 1993; Stanton \& Magnoni, 2008: 6-9). Here, abandonment is viewed as an ongoing process, with activities such as stone-robbing, partial reuse and mortuary activity loosely grouped together as 'post-abandonment processes'. Mortuary activity, other than infant burial (see Millett \& Gowland, 2015) is assumed in this study to have taken place in areas of villa sites that were not being used for other purposes.

The primary basis for the data (Dodd, 2014) has been supplemented by further collection from other gazetteers (De Maeyer, 1937; Scott, 1993), using selection criteria designed to improve the quality of the dataset. Survey data were excluded and the selection limited to sites with at least one excavated building. Many small-scale commercial excavations of villa sites, often available through the French INRAP and British ADS repositories, have been left out because they were not 
Table 1. Site list. Grades refer to the reliability of the data, A being the most reliable.

\begin{tabular}{|c|c|c|c|c|c|}
\hline Site & Location & Grade & Description & Date & References \\
\hline Brislington & UK, near Bristol & B & $\begin{array}{l}\text { Burial remains from lower part of a well, at least } 4 \text { skulls } \\
\text { recovered }\end{array}$ & $\begin{array}{l}\text { Fairly securely dated to } \\
\text { second half of fourth } \\
\text { century }\end{array}$ & Branigan, 1972. \\
\hline Bradford-on-Avon & UK, Wiltshire & A & A single $\mathrm{E}-\mathrm{W}$ oriented grave to west of villa & Fifth century & Corney, 2004. \\
\hline Frocester Court & UK, Gloucestershire & A & $\begin{array}{l}\text { A series of burials, beginning in fifth century, oriented } \mathrm{N}-\mathrm{S} \text { and } \\
\mathrm{E}-\mathrm{W} \text {, from courtyard, seemingly associated with main build- } \\
\text { ing occupation }\end{array}$ & Fifth-seventh century & Price, 2000. \\
\hline Gatcombe & UK, Gloucestershire & B & $\begin{array}{l}\text { Three E-W burials, two of which are double inhumations, } \\
\text { inside Late Antique walls, no grave goods }\end{array}$ & Late Antiquity & Branigan, 1977. \\
\hline Great Witcombe & UK, Gloucestershire & B & $\begin{array}{l}\text { Several fragmentary burials in fifth-century deposits in courtyard } \\
\text { and a single late fourth-century infant burial in south-east } \\
\text { range }\end{array}$ & Late fourth-fifth century & Leach, 1998. \\
\hline Holcombe Farm & UK, Devon & B & $\begin{array}{l}\text { A single infant burial associated with redevelopment of rooms } 1 \\
\text { and } 2\end{array}$ & Early fourth century & Pollard, 1974. \\
\hline Ilchester Mead & UK, Somerset & A & $\begin{array}{l}\text { At least } 4 \text { burials in the site's final phases. Several infant burials } \\
\text { spread throughout east and south building and a single adult } \\
\text { E-W burial }\end{array}$ & & Hayward, 1982. \\
\hline Keynsham & UK, Somerset & $\mathrm{C}$ & $\begin{array}{l}\text { Two 'dumped' graves, one oriented SW-NE, the other } \\
\text { disturbed }\end{array}$ & Dating suspect & Bulleid, 1921. \\
\hline Kingscote & UK, Gloucestershire & $\mathrm{C}$ & Three fragmentary burials, oriented $\mathrm{N}-\mathrm{S}$ without grave cuts & Dating suspect & Timby, 1998. \\
\hline Kingsweston & UK, near Bristol & $\mathrm{C}$ & $\begin{array}{l}\text { A truncated NE-SW inhumation in east of main building; an } \\
\text { E-W burial, without grave cut and with blunt head trauma, in } \\
\text { room } 11\end{array}$ & $\begin{array}{l}\text { Date of both burials perhaps } \\
\text { fifth century, on strati- } \\
\text { graphic evidence }\end{array}$ & Boon, 1950, 1993 \\
\hline North Wraxall & UK, Wiltshire & $\mathrm{C}$ & Two fragmentary burials in upper part of a well & Date unknown & Scrope 1862. \\
\hline Vancelettes Farm & UK, Wiltshire & $\mathrm{C}$ & At least two Post-Roman burials & Post-Roman & Anon., 1990. \\
\hline Westlecote Farm & UK, Wiltshire & $\mathrm{C}$ & $\begin{array}{l}\text { Three burials east of building, two of which described as 'Late } \\
\text { Roman' }\end{array}$ & Late Roman? & Passmore, 1899. \\
\hline Beadlam & $\begin{array}{l}\text { UK, North } \\
\text { Yorkshire }\end{array}$ & B & $\begin{array}{l}\text { A single E-W inhumation, without grave cut, on fourth-century } \\
\text { deposits in room } 7\end{array}$ & $\begin{array}{l}\text { Dated to early fifth century } \\
\text { by associated material }\end{array}$ & Neal, 1996. \\
\hline
\end{tabular}


Table 1. (Cont.)

\begin{tabular}{|c|c|c|c|c|c|}
\hline Site & Location & Grade & Description & Date & References \\
\hline Dalton Parlours & UK, West Yorkshire & A & $\begin{array}{l}\text { A single inhumation in a boundary ditch, with a brooch. Secure } \\
\text { dating from grave goods }\end{array}$ & Fifth-seventh century & $\begin{array}{l}\text { Wrathmell \& Nicholson, } \\
1990 .\end{array}$ \\
\hline Ingleby Barwick & $\begin{array}{l}\text { UK, North } \\
\text { Yorkshire }\end{array}$ & $\mathrm{B}$ & $\begin{array}{l}\text { A N-S inhumation in an abandoned grain drier, itself cutting a } \\
\text { boundary ditch }\end{array}$ & Early fifth century & Wills \& Carne, 2013. \\
\hline Langton & $\begin{array}{l}\text { UK, North } \\
\text { Yorkshire }\end{array}$ & $\mathrm{C}$ & $\begin{array}{l}\text { A N-S oriented double inhumation in courtyard. A second frag- } \\
\text { mentary burial in upper part of a well }\end{array}$ & & Corder \& Kirk, 1932. \\
\hline Rudston & UK, East Yorkshire & A & A fragmentary burial from a well & $\begin{array}{l}\text { Stratigraphy suggests fifth } \\
\text { century date }\end{array}$ & Stead, 1980. \\
\hline Well & $\begin{array}{l}\text { UK, North } \\
\text { Yorkshire }\end{array}$ & $\mathrm{C}$ & $\begin{array}{l}\text { Several fragmentary adult burials and an infant burial in bath- } \\
\text { block }\end{array}$ & Dating suspect & Gilyard-Beer, 1951. \\
\hline Winterton & UK, Lincolnshire & $\mathrm{C}$ & $\begin{array}{l}\text { A small dispersed cemetery of } 5 \text { individuals in Building D and } \\
\text { Orpheus mosaic }\end{array}$ & Date unknown & Stead, 1976. \\
\hline Eccles & UK, Kent & $\mathrm{B}$ & $\begin{array}{l}\text { At least } 3 \text { burials in room } 34 \text { and room 20, and SW of room } 34 \text {. } \\
\text { Orientations unclear. Dated between early third century (cer- } \\
\text { amics) and early fourth century (floor) }\end{array}$ & Third-fourth century & Detsicas, 1968. \\
\hline Fishbourne & UK, West Sussex & $\mathrm{C}$ & $\begin{array}{l}\text { Four extended inhumations, primarily oriented } \mathrm{N}-\mathrm{S} \text {, from east } \\
\text { range of building }\end{array}$ & Date unknown & Cunliffe, 1971. \\
\hline Lullingstone & UK, Kent & A & $\begin{array}{l}\text { Two inhumations in second-century temple, a single infant } \\
\text { burial from fifth-century deposits below collapsed roof in room } \\
15\end{array}$ & Second century; fifth century & Meates, 1979. \\
\hline Thurnham & UK, Kent & A & An infant burial with grave goods, just north of main building & $\begin{array}{l}\text { Mid-third century grave } \\
\text { goods }\end{array}$ & $\begin{array}{l}\text { Booth \& Lawrence, } \\
2006 .\end{array}$ \\
\hline Fleißem-Otrang & $\begin{array}{l}\text { Germany, } \\
\text { Rhineland- } \\
\text { Palatinate }\end{array}$ & $\mathrm{C}$ & Three burials in bath-block, orientation unknown & Date unknown & Koethe, 1929. \\
\hline Remerschen & Luxemburg & $\mathrm{C}$ & Several Late Antique tombs from the villaterrein & Date unknown & Thill, 1970. \\
\hline Schieren-Wieschen & Luxemburg & A & $\begin{array}{l}\text { A single N-S inhumation, dated by Argonne ceramic, in } \\
\text { Building } 3 \text {. Two other inhumations with rubble packing } \\
\text { between Buildings } 1 \text { and } 2\end{array}$ & Fifth century & Biver et al., 2016. \\
\hline Weiler-la-Tour & Luxemburg & $\mathrm{B}$ & A single inhumation in bath-block, dated by stratigraphy & Fourth century & Krier, 1982. \\
\hline Kerkhove-Aveglem & Belgium & $\mathrm{C}$ & A single inhumation in the villaterrein & Mid-fourth century & De Cock \& Rogge, 1988. \\
\hline
\end{tabular}


Table 1. (Cont.)

\begin{tabular}{|c|c|c|c|c|c|}
\hline Site & Location & Grade & Description & Date & References \\
\hline Matagne-la-Petite I & Belgium & A & $\begin{array}{l}\text { A single inhumation dated to late fourth century by ceramic } \\
\text { grave goods. Also, a silver spoon with a chi-rho motif }\end{array}$ & Late fourth century & Plumier, 1987. \\
\hline $\begin{array}{l}\text { Saint-Gérard -Try } \\
\text { Hallot }\end{array}$ & Belgium & $\mathrm{C}$ & $\begin{array}{l}\text { At least } 5 \text { burials, primarily oriented NE-SW spread throughout } \\
\text { Building C }\end{array}$ & Date unknown & Brulet, 1970. \\
\hline $\begin{array}{l}\text { Ewijk-de Grote } \\
\text { Aalst }\end{array}$ & $\begin{array}{l}\text { The Netherlands, } \\
\text { Gelderland }\end{array}$ & A & $\begin{array}{l}\text { Two N-S burials north-west of main house, identified as foeder- } \\
\text { ati burials with belt buckles and weapons }\end{array}$ & $\begin{array}{l}\text { Securely dated to early fifth } \\
\text { century }\end{array}$ & Blom et al., 2012. \\
\hline $\begin{array}{l}\text { HA303, Hambach, } \\
\text { Niederzier }\end{array}$ & $\begin{array}{l}\text { Germany, North } \\
\text { Rhine-Westphalia }\end{array}$ & $\mathrm{C}$ & Villa with an undated burial in sarcophagus inside main building & Late Antiquity & Bayer \& Jürgens, 1995. \\
\hline $\begin{array}{l}\text { HA382, Hambach, } \\
\text { Niederzier }\end{array}$ & $\begin{array}{l}\text { Germany, North } \\
\text { Rhine-Westphalia }\end{array}$ & $\mathrm{B}$ & $\begin{array}{l}\text { Two burials inserted into main building, orientation and } \\
\text { details unknown }\end{array}$ & $\begin{array}{l}\text { Late fourth or early fifth } \\
\text { century }\end{array}$ & Wagner, 2004. \\
\hline $\begin{array}{l}\text { HA69, Hambach, } \\
\text { Niederzier }\end{array}$ & $\begin{array}{l}\text { Germany, North } \\
\text { Rhine-Westphalia }\end{array}$ & $\mathrm{B}$ & Two sarcophagi found north of main building, no details & $\begin{array}{l}\text { Securely dated to late fourth } \\
\text { century }\end{array}$ & $\begin{array}{l}\text { Gaitzsch \& Hermanns, } \\
\quad 1981 .\end{array}$ \\
\hline $\begin{array}{l}\text { HA75, Hambacher } \\
\text { Forst, Niederzier }\end{array}$ & $\begin{array}{l}\text { Germany, North } \\
\text { Rhine-Westphalia }\end{array}$ & $\mathrm{B}$ & Several graves dated by association with coins of Constantine & $\begin{array}{l}\text { Early fourth century, dating } \\
\text { suspect }\end{array}$ & Anon., 1982. \\
\hline Köln-Braunsfeld & $\begin{array}{l}\text { Germany, North } \\
\text { Rhine-Westphalia }\end{array}$ & $\mathrm{B}$ & $\begin{array}{l}\text { At least } 6 \text { tombs, } 5 \text { of which perhaps related to south tower } \\
\text { (converted to a mausoleum and used for fourth-century graves } \\
\text { with glass and other grave goods). Another undated E-W } \\
\text { inhumation, east of main building }\end{array}$ & Fourth century & Fremersdorf, 1930. \\
\hline Köln-Müngersdorf & $\begin{array}{l}\text { Germany, North } \\
\text { Rhine-Westphalia }\end{array}$ & $\mathrm{B}$ & $\begin{array}{l}\text { Three tombs near Speicherturm (storage tower), little informa- } \\
\text { tion available }\end{array}$ & $\begin{array}{l}\text { Fourth century, dating } \\
\text { suspect }\end{array}$ & Fremersdorf, 1933. \\
\hline Köln-Rondorf & $\begin{array}{l}\text { Germany, North } \\
\text { Rhine-Westphalia }\end{array}$ & $\mathrm{B}$ & $\begin{array}{l}\text { Three sarcophagi with late fourth century ceramics and glass. } \\
\text { Limited information but clear dating }\end{array}$ & Late fourth century & Haberey, 1961. \\
\hline $\begin{array}{l}\text { Meerssen- } \\
\text { Onderste- } \\
\text { Herkenberg }\end{array}$ & $\begin{array}{l}\text { The Netherlands, } \\
\text { Limburg }\end{array}$ & $\mathrm{C}$ & A single inhumation on floor of hypocaust & & Scheuermans, 1867. \\
\hline $\begin{array}{l}\text { Rheinbach- } \\
\text { Flerzheim }\end{array}$ & $\begin{array}{l}\text { Germany, North } \\
\text { Rhine-Westphalia }\end{array}$ & A & $\begin{array}{l}\text { Four furnished tombs in cellar of main house, orientation, and } \\
\text { grave goods unknown. }\end{array}$ & $\begin{array}{l}\text { Securely dated to the late } \\
\text { third century }\end{array}$ & Gechter, 1980. \\
\hline Schwirzheim & $\begin{array}{l}\text { Germany, Rhineland } \\
\text { Palatinate }\end{array}$ & $\mathrm{B}$ & $\begin{array}{l}\text { Two burials, one NE-SW and one NW-SE in bath-block and } \\
\text { room } 3 \text {. Poor dating, possibly late fourth century and overlain } \\
\text { in places by fourth-century deposits }\end{array}$ & Possibly late fourth century & Steiner, 1930. \\
\hline $\begin{array}{l}\text { Voerendaal-Ten } \\
\text { Hove }\end{array}$ & $\begin{array}{l}\text { The Netherlands, } \\
\text { Limburg }\end{array}$ & A & $\begin{array}{l}\text { A single E-W oriented inhumation grave east of complex (in } \\
\text { conjunction with cremation), possibly marking a hiatus in } \\
\text { occupation }\end{array}$ & & $\begin{array}{l}\text { Braat, 1953a, 1953b; } \\
\text { Hiddink \& } \\
\text { Habermehl, } 2017 .\end{array}$ \\
\hline
\end{tabular}


Table 2. Breakdown of sites by Late Roman province.

\begin{tabular}{lc}
\hline Late Roman province & No. of studied sites \\
\hline Britannia Prima & 13 \\
Britannia Secunda & 7 \\
Maxima Caesariensis & 4 \\
Belgica Prima & 4 \\
Belgica Secunda & 3 \\
Germania Secunda & 12 \\
\hline
\end{tabular}

excavated to a point at which contextual information about their later phases could be examined in detail. This leaves some areas under-represented, such as Belgica Secunda, where aerial photography has historically been the primary driver for villa identification (Agache, 1978). Once the sites were selected, excluding sites unavailable for analysis despite large-scale excavations, individual site reports were used to select burial data. The distribution of the sites selected is illustrated in Figure 4.

The chronology of these burials is complicated. Traditional scholarship often attributed transitional burials to periods of historical upheaval, for example, the late fourth and early fifth century in Britannia and the late third or early fourth century in Germania Secunda. This has inevitably created biases in the dataset, for example, fourth-century burials dominate the corpus in Britannia. Recent radiocarbon dating of burials, however, indicates that burials spread over longer periods, especially in Britannia, where much of the work has been conducted (Gerrard, 2015; Smith, 2018). This chronological issue is further compounded by the lack of grave goods. Only a few burials, for example at Matagne-la-Petite in Belgium (Plumier, 1987), are closely datable. Most graves in this study are unfurnished and, therefore, difficult to identify. Chronologically, this problem presented a choice: either reject outright traditional identification and invalidate any statistical appreciation of the phenomenon or take burials at face value. Neither of these options was satisfactory, so a blend of the two was selected as viable. The data were graded according to their reliability (grades $\mathrm{A}, \mathrm{B}, \mathrm{C}$, see Table 1), based on a close scrutiny of the site reports. This allows for normative judgements to be made and for burials to be reassessed on stratigraphic information, separating sites into those where dating is relatively secure and those where dating is suspect.

It is not the aim of this article to reassess the much-discussed meaning of the word 'villa' (see e.g. Percival, 1976: 14-15; Willems, 1981; Habermehl, 2014: 17-18) but rather to examine elements of the Late Antique landscape. This study defines the villa as a rectangular, monumentalizing, stone-built, rural building displaying non-functional features that exhibit a degree of Romanized material culture. This approach has been repeatedly used to define the term archaeologically and is common to a variety of studies of Late Antique phases at villa complexes (Van Ossel, 1992: 39-44; Heimberg, 20022003: 68-69; Chavarría, 2007: 32-36).

The transitional burials consist mostly of individuals or small groups. Groups of four or more inhumations are rare in the dataset. These larger groups make up about 23 per cent of the dataset and are concentrated in Germania Secunda and Britannia (Table 3). Although the evidence consists of burials on villaterrein, it should be noted that this is not a villa-specific phenomenon. A variety of other rural settlements, including rural sanctuaries (see Derks \& de Fraiture, 2015), also underwent a similar phase of funerary reuse.

\section{Temporal Dimension}

Traditionally, transitional burials have been identified as a Late Antique phenomenon, with the majority assumed to date to the 


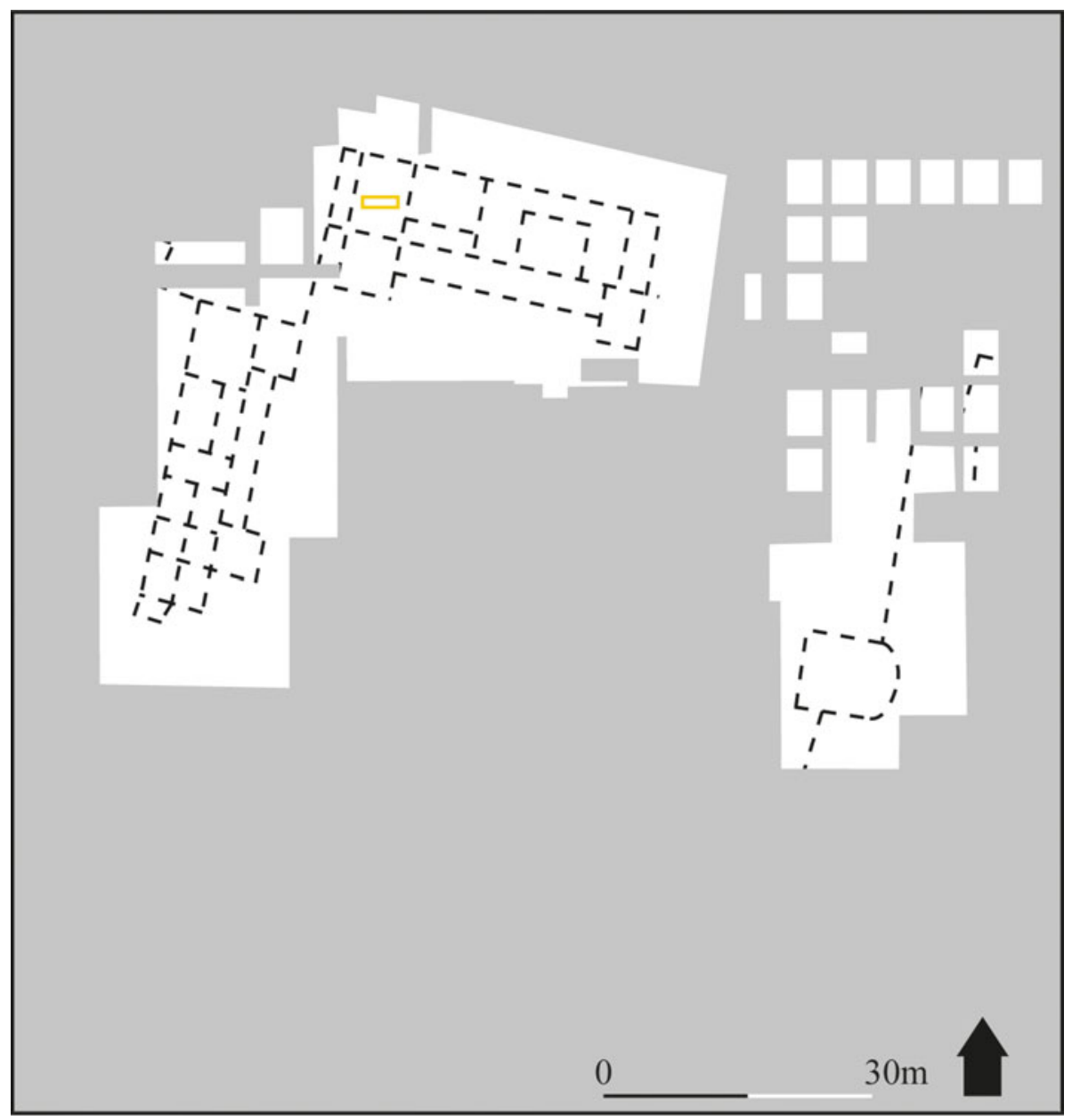

Figure 3. Plan of the Roman villa at Beadlam with a transitional burial of an adult female (in yellow) on a mosaic pavement from phase 4 (sub-Roman) (Dodd, adapted from Neal, 1996: fig. 1).

late fourth century onwards. The Germanic provinces are the exception, with a period of activity in the late third century. These chronological approaches appear in the traditional literature, through the repeated use of terms such as 'Sub-Roman', as well as in modern approaches, which assume that the phenomenon developed towards the end of the Roman period as part of the breakdown of socio-cultural practices associated with the end of the Classical world (Lewit, 2005: 252-54).

The data laid out in Figure 5 show a spike in activity in the fourth century rather than a post-Roman peak, although radiocarbon dating may change this situation in future, if applied to the large 'unknown' variable. Three phases can be discerned: a third-century development phase geographically limited to certain provinces, a fourth-century period of intense use, and a slow decline in activity in the fifth century.

The emergence of the transitional burial phenomenon in the third century suggests that, in some regions, rural populations were burying in villa buildings, either as abandoned areas or as buildings in use. 


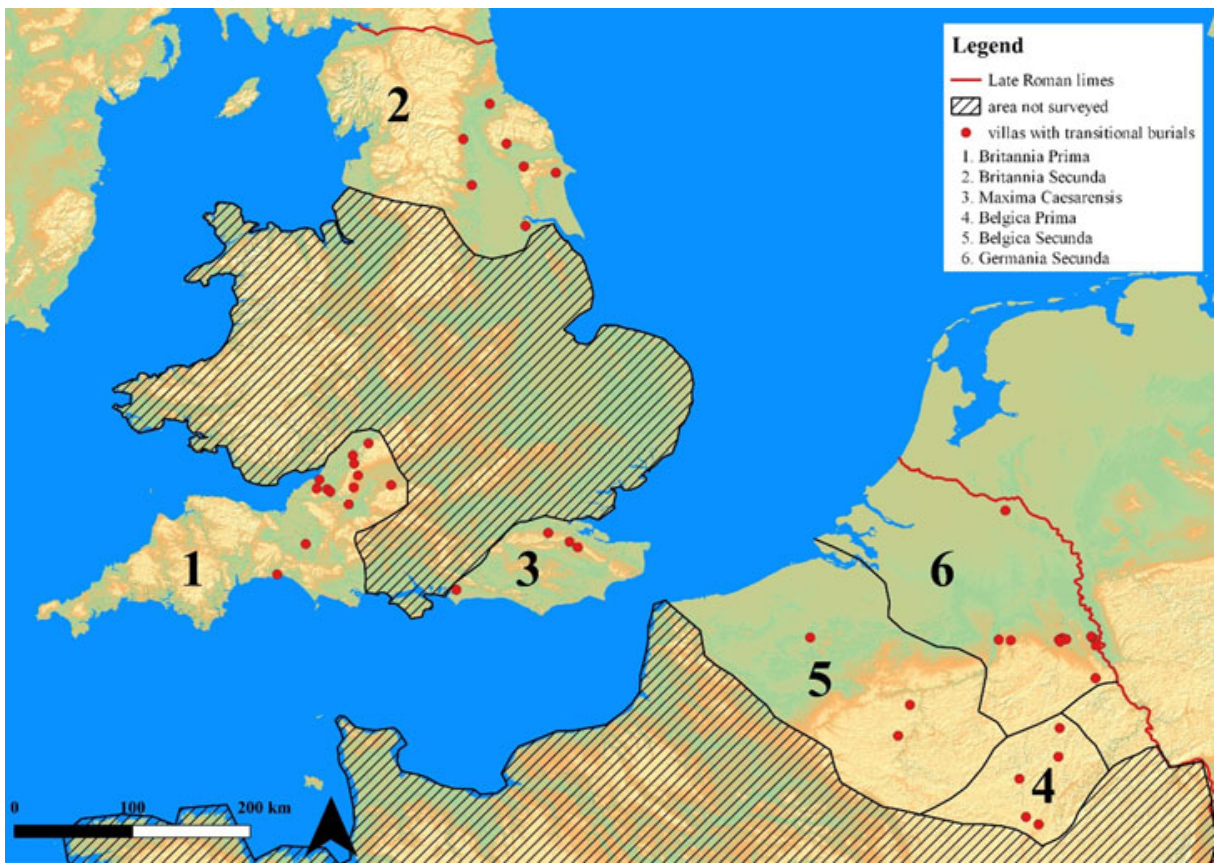

Figure 4. Distribution of transitional burials at villa sites in the study region.

This indicates that it was part of a wider tradition of termination rituals (EsmondeCleary, 2000; Pearce, 2013; Smith, 2018: 234-38). The presence of infant burials (Millett \& Gowland, 2015) as foundation markers is well-researched and, in most cases, differs from the traditions examined in this article. Repeated evidence from this dataset is suggestive of mortuary activity as the final activity in parts of sites or even across entire sites. Eccles in Kent (Detsicas, 1968) is a clear example. The bath complex was decommissioned in the late third century and was marked by three crouched inhumations, dated to the fourth century by the flooring that sealed them. This is mirrored at Schieren-Wieschen in Luxemburg, where a fifth-century burial (Biver et al., 2016) was the last activity in Building 1.

The decrease in the number of burials in the fifth century is most noticeable. This contrasts with long-held views that transitional burials occurred after the formal end of Roman rule. Only the group of burials from Britannia Secunda shows a bias towards the fifth century. Primarily, transitional burials are a feature of the funerary landscape of the fourth century, which indicates two broadly similar trends. First, different attitudes towards the dead were developing across the north-western provinces amongst rural populations, perhaps as a harbinger of the same phenomenon in fifth-century urban centres (Bidwell, 1979: 245-50; Bridger, 2008; Speed, 2014: 101). Second, it suggests that villa buildings were still visible when the individuals were inhumed. This supports the notion that some of these burials were placed rather than 'dumped' into ruins. Many transitional burials were deliberately aligned with the orientation of buildings, for example at Winterton in Lincolnshire (Stead, 1976: 49-50) and Fishbourne in Sussex (Cunliffe, 1971: 219). 
Table 3. Number of sites by burial group size arranged by province.

\begin{tabular}{lcccc}
\hline $\begin{array}{l}\text { Late Roman } \\
\text { province }\end{array}$ & $\begin{array}{c}\mathbf{1} \\
\text { burial }\end{array}$ & $\begin{array}{c}\mathbf{2 - 3} \\
\text { burials }\end{array}$ & $\begin{array}{c}\mathbf{4 - 5} \\
\text { burials }\end{array}$ & $\begin{array}{c}\mathbf{5 +} \\
\text { burials }\end{array}$ \\
\hline $\begin{array}{l}\text { Britannia } \\
\text { Prima }\end{array}$ & 3 & 7 & 2 & 1 \\
$\begin{array}{c}\text { Britannia } \\
\text { Secunda }\end{array}$ & 4 & 2 & 0 & 1 \\
$\begin{array}{c}\text { Maxima } \\
\text { Caesariensis }\end{array}$ & 2 & 1 & 1 & 0 \\
$\begin{array}{c}\text { Belgica Prima } \\
\text { Belgica }\end{array}$ & 1 & 2 & 0 & 1 \\
$\quad$ Secunda & 2 & 0 & 0 & 1 \\
$\begin{array}{c}\text { Germania } \\
\text { Secunda }\end{array}$ & 1 & 8 & 1 & 2 \\
\hline
\end{tabular}

\section{Spatial Dimension}

The assumption that high-status buildings, such as bathhouses, were focal points for transitional burials has been a recurrent topic in the literature (Percival, 1976: 183-99; Lewit, 1991: 41-43, 2005: 256; Le Maho, 1994, 12-13, 19-20). Our data (Figure 6) illustrate a different situation, being dominated by the use of open spaces with other zones less important. This is repeated in all regions, with burials primarily located in courtyards (Corder \& Kirk, 1932: 59) or the villa's wider neighbourhood (Plumier, 1987: 146, figs. 2 \& 3) rather than in high-status zones. Burials in the villaterrein represent a different trajectory but complemented by a preference for domestic zones when burials are interred in existing structures. Burials in bath complexes, contrary to circumstantial data collection, are not very frequent, although they are a widespread sub-set of mortuary practice across most of the north-western provinces. The lack of use of a site's productive areas for burial purposes is a notable divergence from other regions in the Late Roman West (Chavarría, 2007: 134-37). This is not borne out in the data, where the overwhelming preference is for other areas. It may be that productive zones in northwestern Europe experienced more activity in Late Antiquity and were, therefore, not considered suitable for funerary purposes.

The micro-spatial breakdown of transitional burials at villa sites raises questions about the division between burials in the

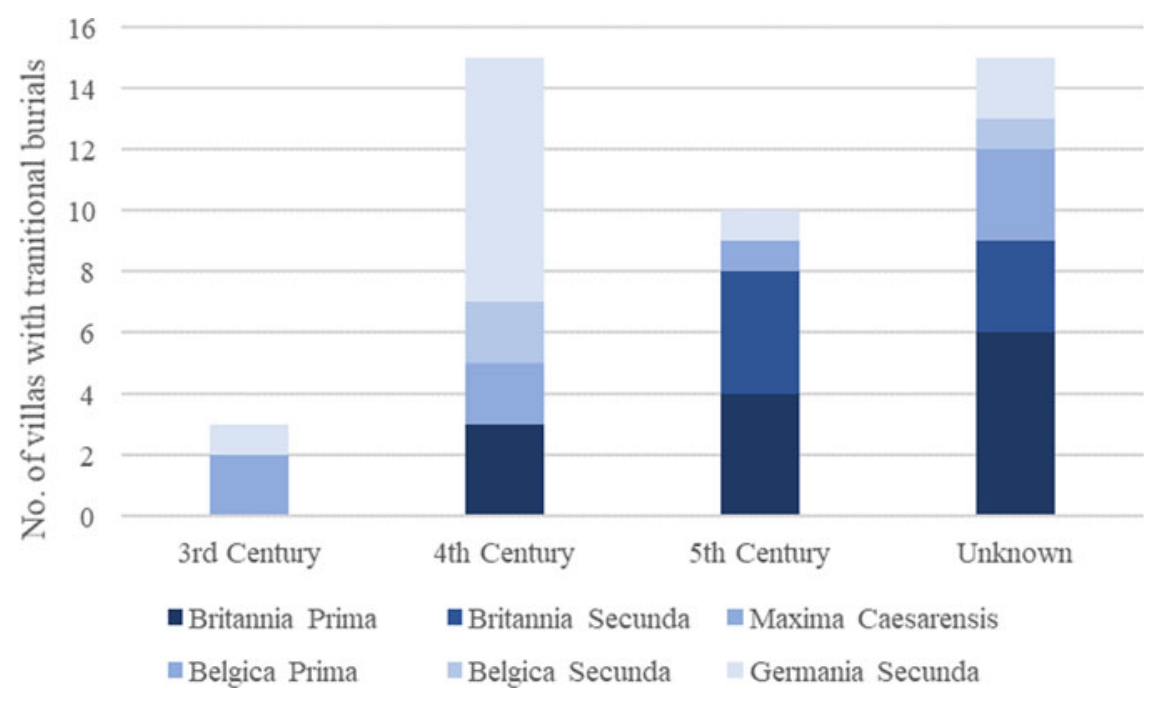

Figure 5. Chronological composition of the dataset, by Late Roman province $(n=43)$. 


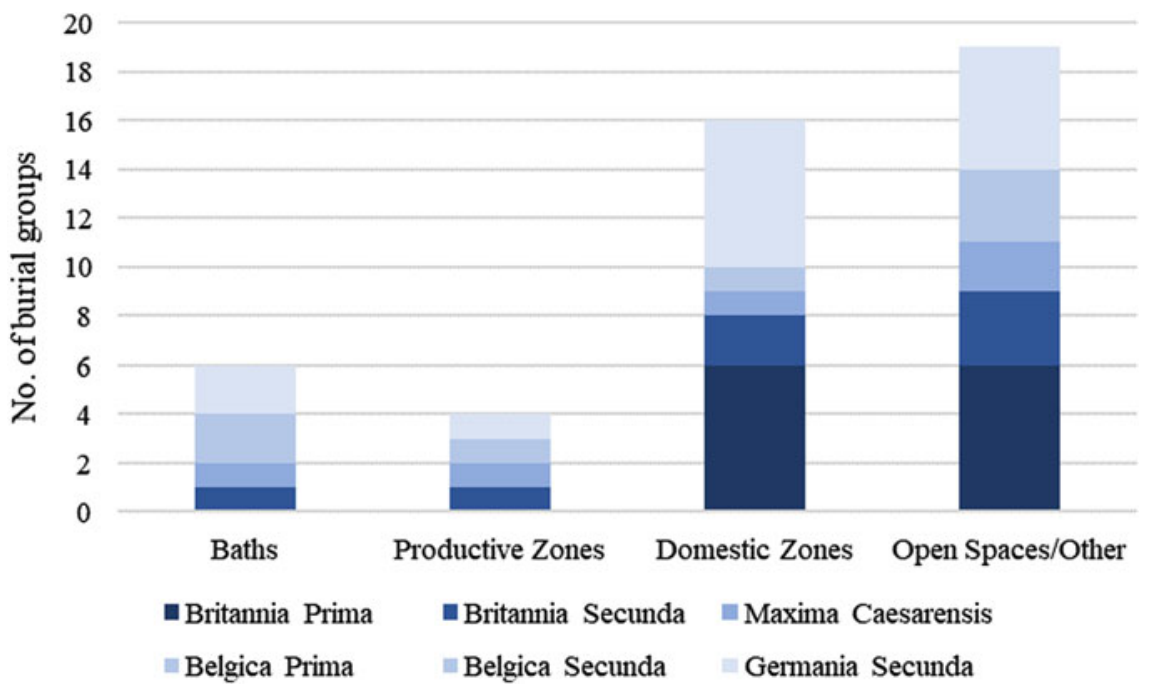

Figure 6. Composition of the location of transitional burials, where data are available $(n=45)$.

wider villaterrein and burials inside domestic zones or bath complexes. Villas with an exterior funerary phase appear to have some occupation on site, for example at Ewijk-De Grote Aalst in the Netherlands, where burials are placed outside the inhabited zone in the early fifth century (Blom et al., 2012: 275-83). This sharply contrasts with burials inside structures, where the individual building or villa site appears to have been abandoned, for example the abandoned Building $\mathrm{C}$ used as a cemetery at Try Hallot in Belgium (Brulet, 1970: 73, fig. 5). This can be tied to the widespread abandonment of sites across the region and is perhaps indicative of a phase of 'termination rituals' in which burials marked the end of occupation rather than the 'specific explanations' traditionally used to describe these graves. The shift from a clearly delimited boundary between occupied and funerary landscapes towards burials moving into villa buildings suggests a significant change in mortuary practices. This may point to a social pattern where there was little or no convention regulating the separation of the landscape of the living and dead and a new pattern of funerary expression developing in lieu of Romanized traditions. Burials marking the end of occupation at villa sits could conceivably have taken place at the same time as post-abandonment activities, such as stone recovery or the temporary use of abandoned sites.

\section{Grave Goods}

Few burials show evidence of grave goods, with only 17.5 per cent of graves containing any (Figure 7). This fits the Late Antique tradition of unfurnished burials (Smith, 2018: 265-68, fig. 6.48), and it is notable that most furnished burials date to the third century and seem to relate to earlier traditions (e.g. Thurnham in Kent: Booth \& Lawrence, 2006: 108-09). Where grave goods are present, there is significant diversity, albeit with a distinct lack of ceramic vessels. Personal adornments dominate and include rings (e.g. Köln-Braunsfeld: Fremersdorf, 1930: 12832), glass vessels (e.g. Köln-Rondorf: Haberey, 1961: 336-39), and military objects (e.g. Ewijk: Blom et al., 2012: 


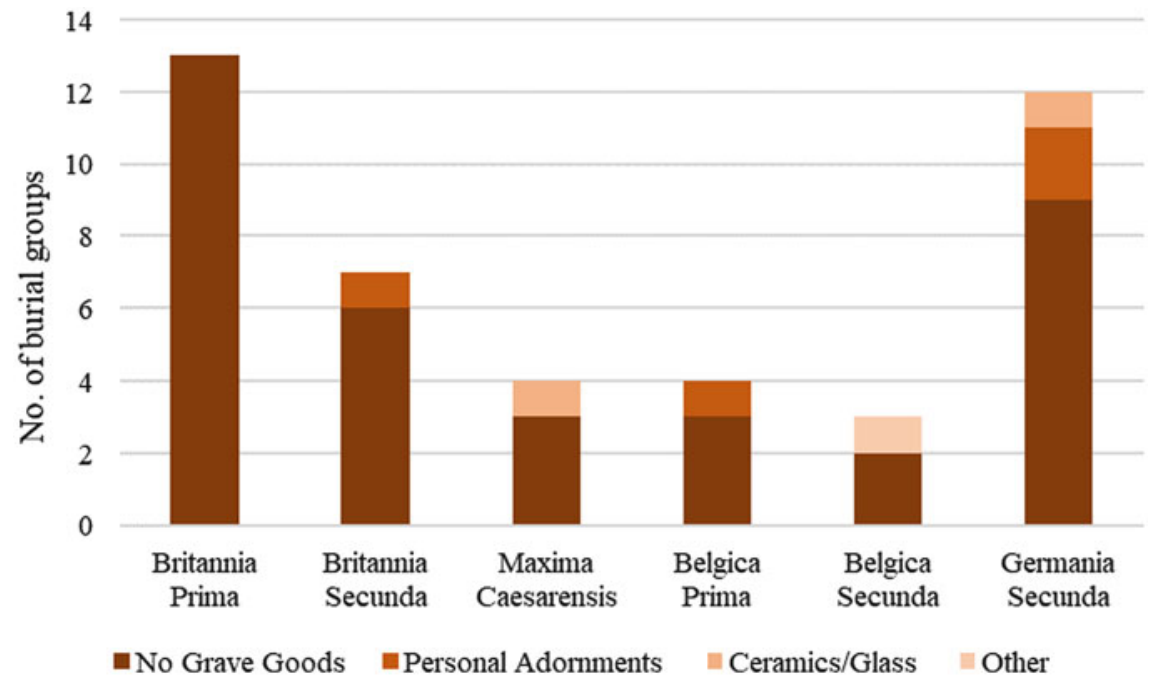

Figure 7. Composition of the types of grave goods in transitional burials, by Late Roman province $(n=42)$.

27-283). In some cases, such as KölnBraunsfeld and Gatcombe in Gloucestershire (Branigan, 1977: 65), there are indications that burials form part of a Christian tradition with overt religious motifs or burials oriented east-west.

Stylistic and cultural-historic analysis of individual graves and their associated artefacts has focused on the divide between unfurnished burials and the richer cemeteries of the Migration period and the creation of binary 'Roman/Barbarian' narratives (see Theuws, 2009; Burmeister, 2016). Traditionally, transitional burials were viewed as 'Roman' in origin because they were unfurnished or contained demonstrable 'Roman' grave goods. Scholarship has repeatedly placed them in the Late Antique mortuary tradition, despite a lack of chronological indicators (Percival, 1976: 183-99).

\section{Conclusions}

The analysis presented here is by no means conclusive but serves to illustrate what can be achieved when evidence from different burials is examined as collectively rather than on a case-by-case basis. The key finding in this paper is the lack of disparity between Britannia and the continental provinces, suggesting they are not as divergent as has been thought (e.g. Gerrard, 2013). The distribution of burials suggests that villa-using populations in Belgica, Germania Secunda, and Britannia had the same form of funerary expression over the course of Late Antiquity. This supra-regional approach to funerary expression may indicate that similar factors were influencing the development of the phenomenon across large regions, rather than limited socio-cultural trends. Despite transitional burials in villas being a widespread phenomenon, their time span is short. The evidence so far, although future radiocarbon dating could radically change this picture, suggests a peak of intensity in the fourth century and little use of villa sites for this purpose beyond the fifth century. The decline of transitional burials may point to new realities in the post- 
Roman fifth century and the appearance of new population groups in north-western Europe (Heeren, 2015) not engaging in this form of mortuary expression. From the mid-fifth century onwards, larger cemeteries with hybridizing styles (Heeren \& Roymans, 2018), many with features identified as 'Germanic' (Halsall, 2009), replaced transitional burials as the primary form of funerary expression on villa sites in both Britannia and north-western Gaul.

Our data suggest that two separate traditions can be discerned: the use of the wider villa landscape for burial when the site was in occupation, and the use of abandoned (or partially abandoned) zones for termination rituals. The first is visible in the increasing spatial diversity of burials across the wider villaterrein, rather than in the clustered cemeteries of the Middle Roman period in continental Europe and rural cemeteries in Britannia. Although this appears to be a break from the past, it is a less dramatic rupture than would first appear. The Classical taboo between life and death was retained and clear divisions between operational structures and the funerary landscape maintained. The second tradition appears to act as a form of 'termination ritual' (Merrifield, 1987), in which burials were used to seal off abandoned areas of a site; it is linked to similar uses of animal burials (King \& Grande, 2015: 9). Such 'dumped' burials, as they used to be interpreted, are present on a variety of sites, where burials act as the final activity overall or in certain sectors of sites. The phenomenon requires much more investigation: without further radiocarbon dating work, little more can be added.

The meaning of these 'casual' burials has long created interpretative problems in developing a 'neat' solution for the end of the villa landscape. Consequently, archaeologists instead developed specific explanations for individual burials. It seems likely that we merged two conflicting trends and assumed they represented the same phenomenon. Burials inside buildings were probably related to the termination rituals of entire sites or zones within them, with other buildings being given over to burial upon decommissioning. The alignment of many of these burials with the structures on site suggests that the deceased were not simply 'dumped' but carefully positioned to take advantage of the visible ruins. One notable aspect of this situation is that transitional funerary use of some buildings was concurrent with quarrying, including the reclamation of building material, illustrating the multiple trajectories that a site can follow after the end of its formal use. Burials in the wider villaterrein are a different phenomenon, highlighting the changing nature of Late Antique habitation within an occupied and productive landscape. There are significant differences compared to burials inside abandoned buildings, especially with respect to grave goods. Within this group, the Classical taboo (i.e. separation of the realm of the dead from that of the living) was maintained; but the apparent lack of clearly defined cemeteries on the sites' edges suggests that this was no longer strictly applied.

These patterns indicate that the villa landscapes of the north-western provinces underwent large-scale social change, reflected in burial practices and the shifting priorities of rural populations in the northwestern provinces during Late Antiquity. They hint at new socio-economic conditions, which encouraged the abandonment and termination of villa settlements across the region and began to erode the important separation between life and death.

\section{REFERENCES}

Agache, R. 1978. La Somme pré-romaine et romaine d'après les prospections aériennes à 
basse altitude. Amiens: Société des Antiquaires de Picardie.

Anon. 1982. Ausgrabungen and Funde. Bonner Jahrbücher, 182: 457-547.

Anon. 1990. Excavations and Fieldwork in Wiltshire 1988. Wiltshire Archaeological and Natural History Magazine, 83: 222.

Barker W.R. 1901. Remains of a Roman Villa Discovered at Brislington, Bristol, December 1899. Transactions of the Bristol E Gloucestershire Archaeological Society, 24: 283-92.

Beyer, B. \& Jürgens, A. 1995. Rheinisches Amt für Bodendenkmalpflege. Ausgrabungen, Funde und Befunde 1993. Bonner Jabrbücher, 195: 457-575.

Bidwell, P.T. 1979. The Legionary Bathhouse and Basilica and Forum at Exeter. Exeter: Exeter City Council \& University of Exeter.

Biver, V., Stead, A.J. \& Polfer, M. 2016. Le domaine de la villa gallo-romaine de Schieren (G.-D. de Luxembourg): contexte archéologique et résultats préliminaires des fouilles récentes. Archaeologica Luxemburgensis, 3: 42-63.

Blom, E., van der Feijst, L.M.B. \& Veldman, H.A.P. 2012. Plangebied Keizershoeve I Archeologisch onderzoek op 'De Grote Aalst' te Ewijk rapport 2000. Amersfoort: ADC.

Boon, G.C. 1950. Excavations at King's Weston. Transactions of the Bristol E' Gloucestershire Archaeological Society, 69: 5-58.

Boon, G.C. 1993. Kingsweston Villa Revisited: The East Wing Murder and Other Burials. Transactions of the Bristol E Gloucestershire Archaeological Society, 111: 73-83.

Booth, P. \& Lawrence, S. 2006. The Iron Age Settlement and Roman Villa at Thurnham, Kent. Oxford: Oxford Wessex Archaeology Joint Venture.

Braat, W.C. 1953a. Opgravigen bij de Romeins villa Voerendaal - Ten Hove. Oudheidkundige Mededelingen uit 's Rijkmuseum van Oudheiden te Leiden, 34: 43-49.

Braat, W.C. 1953b. De grote Romeinse villa van Voerendaal. Oudheidkundige Mededelingen uit 's Rijkmuseum van Oudheiden te Leiden, 34: 49-79.

Branigan, K. 1972. The Romano-British Villa at Brislington. Proceedings of the Somerset Natural History and Archaeology Society, 116: 78-85.
Branigan, K. 1977. Gatcombe Roman Villa. Oxford: Archaeopress.

Bridger, C. 2008. Die Gräber der Spätantike (275-ca. 430 n. Chr.). In: M. Müller, N. Zieling \& H.J. Schalles, eds. Colonia Ulpia Traiana. Xanten und sein Umland in römischer Zeit. Mainz: Philip von Zabern, pp. 583-94.

Brulet, R. 1970. La villa romaine du TryHallot à Saint-Gérard. Étude topographique. Recherches d'archéologie et d'histoire de l'art (Antiquité) : Section d'archéologie et d'bistoire de l'art, 6: 63-80.

Brulet, R. 1990. La Gaule septentrionale au Bas-Empire : occupation du sol et défense du territoire dans l'arrière-pays du Limes aux $I V e$ et $V e$ siècles. Trier: Landesmuseum Trier.

Bulleid, A. 1921. The Roman House at Keynsham, Somerset. Journal of Roman Studies, 11: 210-14.

Burmeister, S. 2016. Archaeological Research on Migration as a Multidisciplinary Challenge. Medieval Worlds, 4: 42-64.

Cameron, C.M. \& Tonka, S.A. eds. 1993. Abandonment of Settlements and Regions: Ethnoarchaeological and Archaeological Approaches. Cambridge: Cambridge University Press.

Cantino Wataghin, G. 1999. “... ut haec aedes Christo Domino in ecclesiam consecratur". Il riuso cristiano di edifici antichi tra tarda antichità e alto medioevo. Ideologie e pratiche del reimpiego nell'alto Medioevo, 16: 673-750.

Chavarría, A. 2004. Interpreting the Transformation of Late Roman Villas: The Case of Hispania. In: N. Christie, ed. Landscapes of Change: Rural Evolutions in Late Antiquity and the Early Middle Ages. Abingdon: Routledge, pp. 67-102.

Chavarría, A. 2007. El final de las villas en Hispania (siglos IV-VIII). Turnhout: Brepols.

Chavarría, A. 2018. People and Landscapes in Northern Italy: Interrogating the Burial Evidence. In: P. Diarte Blasco \& N. Christie, eds. Interpreting the Transformations of People and Landscapes in Late Antiquity and the Middle Ages. Oxford: Oxbow, pp. 163-78.

Christie, N. 2004. Landscapes of Change in Late Antiquity and the Early Middle Ages. In: N. Christie, ed. Landscapes of Change: Rural Evolutions in Late Antiquity 
and the Early Middle Ages. Abingdon: Routledge, pp. 1-38.

Corder, P. \& Kirk, J.L. 1932. A Roman Villa at Langton, Near Malton, E. Yorkshire. York: Roman Antiquities Committee of the Yorkshire Archaeological Society.

Corney, M. 2004. The Roman Villa at Bradford-on-Avon: The Investigations of 2003. Stroud: Libris.

Cunliffe, B. 1971. Fishbourne 1961-1969 Volume I: The Site. London: Society of Antiquaries.

De Boe, G. \& Van Imp, L. 1979. Nederzetting uit de ijzertijd en Romeinse villa te Rosmeer. Brussels: Nationale Dienst voor Opgravingen.

De Cock, C.S. \& Rogge, M. 1988. De V.O. B.o.W. activiteiten te Kerkhove (gem. Avelgem) in 1986-1987. Westvlaamse Archeologica, 4: 13-19.

De Maeyer, R. 1937. De Romeinsche villa's in België. Een archeologische studie. Antwerpen: Martinus Nijhoff.

Derks, T. \& de Fraiture, B. eds. 2015. Een Romeins heiligdom en een vroegmiddeleeuws grafveld bij Buchten (L.). Verslag van een archeologisch noodonderzoek (1976). Amersfoort: Rijksdienst voor het Cultureel Erfgoed.

Detsicas, A.P. 1968. Excavations at Eccles Roman Villa, 1967: Sixth Interim Report. Archaeologia Cantiana, 83: 39-48.

Dodd, J. 2014. A Preliminary Quantification of 'Squatter' Occupation in the Villas of Late Roman Britain (unpublished MA dissertation, University of Newcastle-upon-Tyne).

Dodd, J. 2019. A Conceptual Framework to Approaching Late Antique Villa Transformation Trajectories. Journal of Archaeology and Ancient History, 6: 30-44. https://doi.org/10.14795/j.v6i1.359.

Esmonde-Cleary, S. 1989. The Ending of Roman Britain. London: Batsford.

Esmonde-Cleary, S. 2000. Putting the Dead in their Place: Cemetery Location in Roman Britain. In: J. Pearce, M. Millett \& M. Struck, eds. Burial, Society and Context in the Roman World. Oxford: Oxbow, pp. 127-42.

Farwell, D. \& Molleson, T. 1993. Poundbury, Vol. 2 The Cemeteries. Dorchester: Dorset Natural History and Archaeological Society.

Ferdière, A. ed. 1993. Monde des morts, monde des vivants en Gaule rurale. Tours: Université de Tours.
Fremersdorf, F. 1930. Der römische Gutshof in der Stolberger Strasse zu Köln Braunsfeld. Bonner Jahrbücher, 135: 128-40. https://doi.org/10.11588/bjb.1930.0.38464.

Fremersdorf, F. 1933. Der Romische Guthof Koln-Mungersdorf. Berlin: de Gruyter.

Gaitzsch, W. \& Hermanns, J. 1981. Eine römische Hofanlage im "München Busch" bei Niederzier, Kr. Düren. Ausgrabungen im Rheinland '79/80: 133-35.

Gechter, M. 1980. Römische Zeit: Die römische Villa rustica von RheinbachFlerzheim. Ausgrabungen im Rheinland '79: 173-77.

Gerrard, J. 2013. The Ruin of Roman Britain: An Archaeological Perspective. Cambridge: Cambridge University Press.

Gerrard, J. 2015. Synthesis, Chronology, and 'Late Roman' Cemeteries in Britain. American Journal of Archaeology, 119: 56572. https://doi.org/10.3764/aja.119.4.0565.

Gilyard-Beer, R. 1951. The Romano-British Baths at Well. York: Yorkshire Archaeological Society.

Gorges, J.-C. 1979. Les villas hispano-romaines: inventaire et problématique archéologiques. Paris: De Boccard.

Grenier, A. 1934. Manuel d'archéologie galloromaine, tome 2 : l'archéologie du sol, les routes, la navigation, l'occupation du sol. Paris: Picard.

Haberey, W. 1961. Römische Grabkammer bei Rondorf, Ldkr. Köln. Bonner Jahrbücher, 161: 333-42.

Habermehl, D. 2014. Settling in a Changing World: Villa Development in the NorthWest Provinces of the Roman Empire. Amsterdam: Amsterdam University Press.

Halsall, G. 1995. Early Medieval Cemeteries: An Introduction to Burial Archaeology in the Post-Roman West. Glasgow: Cruithne Press.

Halsall, G. 2009. Cemeteries and Society in Merovingian Gaul. Leiden: Brill.

Hatton, R.C. 1999. The Cemeteries in Roman Britain: Evidence for Management and Related Social Implications, with Particular Reference to the late Roman Period (unpublished $\mathrm{PhD}$ dissertation, University of Sheffield).

Hayward, L.C. 1982. Ilchester Mead Roman Villa. Stroud: Toucan Press.

Heeren, S. 2015. The Depopulation of the Lower Rhine in the 3rd Century: An Archaeological Perspective. In: N. 
Roymans, T. Derks \& H.A. Hiddink, eds. The Roman Villa at Hoogeloon and the Archaeology of the Periphery. Amsterdam: Amsterdam University Press, pp. 271-95.

Heeren, S. 2016. The Theory of 'Limesfall' and the Material Culture of the Late 3rd Century. Germania, 94: 185-209. https:// doi.org/10.11588/ger.2016.39072.

Heeren, S. \& Roymans, N. 2018. Contextualising Ethnicity and the Rhetoric of Burial Rites in Late Antique Northern Gaul: The Evidence from Settlements and Precious Metal Circulation. In: M. Kars, R. van Oosten, M.A. Roxburgh \& A. Verhoeven, eds. Rural Riches $E^{\circ}$ Royal Rags? Studies on Medieval and Modern Archaeology Presented to Frans Theuws. Zwolle: Spa Uitgevers, pp. 8-14.

Heimberg, U. 2002-2003. Römische Villen an Rhein und Maas. Bonner Jahrbücher, 202/ 203: 57-146. https://doi.org/10.11588/bjb. 2002.0.42250.

Hiddink, H. \& Habermehl, D. 2017. De Romeinse villa van Voerendaal-Ten Hove Plan van aanpak voor uitwerking en publicatie. Amersfoort: RCE.

Joerres, P. 1886. Römische Niederlassungen an der Ahr. Bonner Jahrbücher, 82: 82-93. https://doi.org/10.11588/bjb.1886.0.45453.

Kießling, P. 2008. Die villa rustica HA 412 und das Römische Gräberfeld HA 86/158 (unpublished $\mathrm{PhD}$ dissertation, Rheinischen Friedrich-Wilhelms-Universität Bonn).

King, A. \& Grande, M. 2015. Dinnington and Yarford: Two Roman Villas in South and West Somerset. In: M. Henig, G. Soffe \& K. Adcock, eds. Villas, Sanctuaries and Settlement in the Romano-British Countryside: New Perspectives and Controversies. Oxford: Oxbow, pp. 2-22.

Koethe, H. 1929. Der römische Gutshof bei Otrang. Trierer Zeitschrift, 4: 75-83.

Krier, J. 1982. Ausgrabungen in Weiler-latour (Mèchel-Lëtschweiler). Hémecht, 34: 93-110.

Leach, P. 1998. Great Witcombe Roman Villa, Gloucestershire: A report on the Excavations by Ernest Greenfield 1960-1973. Oxford: Archaeopress.

Leech, R. 1981. The Excavation of a Romano-British Farmstead and Cemetery on Bradley Hill, Somerset. Britannia, 12: 177-252. https://doi.org/10.2307/526249.

Le Maho, J. 1994. La réutilisation funéraire des édifices antiques en Normandie au cours du haut Moyen-Âge. In: M. Fixot \& E. Zadora-Rio, eds. L'environnement des églises et la topographie religieuse des campagnes médiévales. Paris: Société d'Archéologie médiévale, pp. 10-21.

Lesenne, M. 1975. Bibliografisch repertorium van de oudheidkundige overblijfselen te Tongeren. Brussels: Oudheidkundige repertoria.

Lewit, T. 1991. Agricultural Production in the Roman Economy, 200-400 AD. Oxford: Archaeopress.

Lewit, T. 2001. Changing Concepts of Late Antiquity: The Decline and Fall of Gibbonism. Bulletin de l'Antiquité tardive, 10: $33-37$.

Lewit, T. 2003. 'Vanishing Villas': What Happened to the Elite Rural Habitations in the West in the 5th-6th Centuries? Journal of Roman Archaeology, 16: 260-74. https:// doi.org/10.1017/S104775940001309X.

Lewit, T. 2005. Bones in the Bathhouse: Reevaluating Squatter Occupation at 5 th to 6th Century Villas. In: G.P. Brogiolo, A. Chavarría \& M. Valenti, eds. Dopo la fine delle ville: le campagne dal VI al IX secolo. Mantova: Società Archeologica Padana, pp. 251-62.

Mattingly, D. 2007. An Imperial Possession: Britain in the Roman Empire $54 B C-A D$ 409. London: Penguin.

Meates, G.W. 1979. Lullingstone Roman Villa Part 1. Canterbury: Kent Archaeological Society.

Merrifield, R. 1987. The Archaeology of Ritual and Magic. London: Batsford.

Millett, M. \& Gowland, R. 2015. Infant and Child Burial Rites in Roman Britain: A Study from East Yorkshire. Britannia, 46: 171-89.

Morris, I. 1992. Death, Ritual and Social Structure in Classical Antiquity. Oxford: Archaeopress.

Neal, D.S. 1996. Excavations on the Roman Villa at Beadlam. Leeds: Yorkshire Archaeological Society.

Oswald, A. 1937. A Roman Fortified Villa at Norton Disney, Lincs. The Antiquaries Journal, 17: 138-78. https://doi.org/10. 1017/S0003581500038506.

Passmore, A.D. 1899. Notes on a Roman Building and Internments, Lately Discovered at Swindon. The Wiltshire Archaeological and Natural History Magazine, 30: 217-21.

Pearce, J. 2013. Contextual Archaeology of Burial Practice: Case Studies in Roman Britain. Oxford: Archaeopress. 
Percival, J. 1976. The Roman Villa: A Historical Introduction. Manchester: Batsford.

Percival, J. 1992. The Fifth-Century Villa: New Life or Death Postponed? In: J. Elton \& H. Drinkwater, eds. Fifth Century Gaul: A Crisis of Identity? Cambridge: Cambridge University Press, pp. 156-65.

Petts, D. 1997. Elite Settlements in the Roman and Sub-Roman Periods. In: K. Meadows, ed. Proceedings of the Sixth Theoretical Roman Archaeology Conference (TRAC), Sheffield, 1996. Oxford: Oxbow, pp. 101-12.

Pignoil, A. 1972. L'Empire Chrétien (325395). Paris: Presses Universitaires de France.

Plumier, J. 1987. Structures gallo-romaines á Bieure, Matagne-la-Petite (Comm. de Doische). Archaeologia Belgica, 111: 14252.

Pollard, S. 1974. A Late Iron Age Settlement and a Romano-British Villa at Holcombe, near Uplyme, Devon. Proceedings of the Devon Archaeological Society, 32: 59-161.

Price, E. 2000. Frocester: A Romano-British Settlement its Antecedents and Successors Vol $I$ and II. Stonehouse: Gloucester and District Archaeological Group.

Rémondon, R. 1964. La crise de l'empire romain de Marc-Aurèle à Anastatse. Paris: Presses Universitaires de France.

Ripoll, G. \& Arce, J. 2000. The Transformation and End of Roman Villas in the West (Fourth-Seventh Centuries: Problems and Perspectives). In: G.P. Brogiolo, N. Gauthier \& N. Christie, eds. Towns and their Territories Between Late Antiquity and the Early Middle Ages. Leiden: Brill, pp. 63-114.

Schiffer, M. 1987. Formation Processes of the Archaeological Record. Albuquerque (NM): University of New Mexico Press.

Schuermans, H. 1867. Explorations de villas Belgo-Romaines outre Meuse II. Fouilles dans les substructions de Herkenberg (Meerssen), Bulletin des Commissions royales d'Art et d'Archéologie de Belgique, 6: 229-303.

Scott, E. 1993. A Gazetteer of Roman Villas in Britain. Leicester: Leicester University Press.

Scott, E. 1999. The Archaeology of Infancy and Infant Death. Oxford: Archaeopress.

Scott, E. 2018. Three burials at Norton Disney and the End of Roman Villas in
Britain (blog). Available at: https://eleanorscottarchaeology.com/els-archaeologyblog/2018/1/29/three-burials-at-nortondisney-and-the-end-of-roman-villas-inbritain

Scrope, G.P. 1862. On a Roman Villa Discovered at North Wraxall. The Wiltshire Archaeological and Natural History Magazine, 7: 59-74.

Smith, A. 2018. Death in the Countryside: Rural Burial Practices. In: A. Smith, M. Allen, T. Brindle, M. Fulford \& L. Lodwick, eds. Life and Death in the Countryside of Roman Britain: New Visions of the Countryside of Roman Britain, Volume 3. London: Roman Society Publications, pp. 205-80.

Speed, G. 2014. Towns in the Dark? Urban Transformations from Late Roman Britain to Anglo-Saxon England. Oxford: Archaeopress.

Stanton, T.W. \& Magnoni, A. eds. 2008. Ruins of the Past: The Use and Perception of Abandoned Structures in the Maya Lowlands. Denver (CO): University Press of Colorado.

Stead, I.M. 1976. Excavations at Winterton Roman Villa and other Roman Sites in North Lincolnshire 1958-1967. London: Department of the Environment.

Stead, I.M. 1980. Rudston Roman Villa. York: Yorkshire Archaeological Society.

Steiner, P. 1930. Romische Baureste in Schwirzheim. Trierer Zeitschrift, 5: 93-98.

Storrie J. 1908. Report on Excavations near Llantwit Major. Transactions of the Cardiff Naturalists' Society, 20: 49-62.

Swain, E.J. 1976. KAA Excavations: The Chessalls, Kingscote 1975-1976. Stroud: Kingscote Archaeological Association.

Theuws, F.C.W.J. 2009. Grave Goods, Ethnicity, and the Rhetoric of Burial Rites in Late Antique Northern Gaul. In: N. Roymans \& T. Derks, eds. Ethnic Constructs in Antiquity: The Role of Power and Tradition. Amsterdam, Amsterdam University Press, pp. 283-317.

Thill, G. 1970. Um eine 'versunkene' Römervilla bei Remerschen (auf 'Mecheren' an der Mosel). Hémecht, 22: 455-67.

Timby, J. 1998. Excavations at Kingscote and Wycomb, Gloucestershire. Reading: Cotswold Archaeology. 
Van Ossel, P. 1992. Établissements ruraux de l'Antiquité tardive dans le nord de la Gaule. Paris: Gallia Supplément.

Van Ossel, P. \& Ouzoulias, P. 2000. Rural Settlement Economy in Northern Gaul in the Late Empire: An Overview and Assessment. Journal of Roman Archaeology, 13: 133-60. https://doi.org/10.1017/ S104775940001881X.

Wagner, G. 2004. Die Gräber der villa rustica HA 382 (unpublished MA dissertation, University of Cologne).

Whiting, C.E. 1941. Excavations at Stancil 1938-1939. Yorkshire Archaeological Journal, 35: 261-69.

Wightman, E. 1985. Gallia Belgica. London: Batsford.

Willems, W.H.J. 1981. Romans and Batavians: A Regional Study in the Dutch Eastern River Area I. Berichten van de Rijksdienst voor het Oudheidkundig Bodemonderzoek, 31: 7-217.

Wills, S. \& Carne, P. 2013. A Roman Villa on the Edge of Empire: Excavations at Ingleby Barwick, Stockton-on-Tees 2003-2004.
Durham: Durham University Archaeological Service.

Wrathmell, S. \& Nicholson, A. 1990. Dalton Parlours: Iron Age Settlement and Roman Villa. Leeds: West Yorkshire Archaeological Service.

\section{Biographical Notes}

James Dodd is a $\mathrm{PhD}$ candidate at the Vrije Universiteit Amsterdam specializing in rural transformation in the Late Roman period.

Address: Faculty of Humanities, Department of Archaeology, Classics and Near Eastern Studies, De Boelelaan 1105, 1081 HV Amsterdam, The Netherlands. [email: j.a.1.d.dodd@vu.nl]. ORCID: 0000-0002-9165-6907.

\section{Les sépultures transitoires à la fin de l'Antiquité tardive dans les provinces nord- occidentales d'Europe : évaluation de leur répartition et attributs}

Dans le paysage des provinces du nord-ouest de l'Europe, la fin de son exploitation par les villas romaines marque une importante période de transformation. L'utilisation des villas et de leurs domaines à des fins funéraires en constitue un aspect. Ces sépultures ont traditionnellement été séparées en deux classes : celles qui reflètent une réutilisation des sites à grande échelle pendant l'époque des grandes migrations et celles qui documentent un phénomène transitoire à petite échelle, un phénomène souvent mal compris ou négligé. L'auteur de cet article examine ces sépultures transitoires dans leur contexte historique et propose une nouvelle approche permettant d'évaluer l'ampleur, la répartition temporelle et les attributs d'un groupe de sites incorporant des éléments funéraires dans les provinces romaines nordouest de l'Europe. Translation by Madeleine Hummler

Mots-clés: Antiquité tardive, provinces nord-occidentales, rites funéraires, transformation des villas, habitat rural, époque des grandes migrations

\section{Die Gräber der spätantiken Übergangsphase in den Villen der nordwestlichen römischen Provinzen: eine Bewertung ihrer Eigenschaften und Verteilung}

Erhebliche Veränderungen kennzeichnen das Ende der Villenlandschaft in den nordwestlichen römischen Provinzen, darunter die Wiederbenutzung der Villen und deren Umgebung als Bestattungsstätten. Traditionell hat man zwischen Gräber in einer umfangreichen Wiederbenutzung von Fundorten in der Völkerwanderungszeit und kleinere, vorübergehende Bestattungen unterschieden. Die Untersuchung solcher Gräber wurde oft vernachlässigt oder irrig durchgeführt. In diesem Artikel werden die Bestattungen der Übergangsphase in ihrem historischen Kontext untersucht und eine neue 
Vorgehensweise vorgeschlagen. Letztere hat das Ziel, den Umfang, die Verbreitung und die Eigenschaften einer Gruppe von Bestattungsstätten in den Provinzen von Germania, Belgica und Britannia zu bewerten. Translation by Madeleine Hummler

Stichworte: Spätantike, nordwestliche Provinzen, Grabsitten, Veränderung der Villen, ländliche Siedlungen, Völkerwanderungszeit 